\title{
(j)
}

AL-DZIKRA

Jurnal Studi Ilmu Al-Qur'an Dan Al-Hadits http://ejournal.radenintan.ac.id/index.php/al-dzikra Volume 13, No. 1, Juni Tahun 2019, Halaman 1 - 26

DOI://dx.doi.org/10.24042/al-dzikra.v13i1.3666

\section{MANAHIJ TAFSIR TABI'IN MUJAHID BIN JABAR DAN PENAFSIRANNYA}

\begin{tabular}{c}
\hline Eko Zulfikar \\
IAIN Tulungagung \\
ekozulfikar2020@gmail.com \\
\hline
\end{tabular}

\section{Abstract}

This paper tries to explore the work of tafsir tabi'in, Mujāhid bin Jabar. By reading it from the perspective of constructivism with pure literature studies and analysis of intertextuality data, the author can identify the existence of Mujähid interpretation of hid, which at least there are two interpretive sources used by the author in interpreting the Qur'an; (1) the source of bi alma'tsur, that is based on the Qur'an's own explanation, in addition to the prophetic traditions, opinions of prophet's companion, and also israiliyyāt (2) the source of bi al-ra'yi, based on the ijtihad of the interpreter. While in explaining the Qur'an, the method that Mujāhid carried is the ijmâti method, which is to interpret the verses of the Qur'an in a brief language, solid, and not lengthy, also using the muqaaran method although only slightly. For his interpretive style, Mujāhid's interpretation does not extend to any particular discipline, only limited with the feel of interpretation of his teacher - Ibn 'Abbass, although in some interpretations there is a fiqhi and kalämi pattern with very little capacity. 


\section{Abstrak}

Tulisan ini mencoba melakukan eksplorasi terhadap karya tafsir tabi'in, Mujāhid bin Jabar. Dengan membacanya dari perspektif konstruktivisme dengan murni studi pustaka dan analisa data intertekstualitas, penulis dapat mengindentifikasi keberadaan tafsir Mujāhid, yang sekurangnya terdapat dua sumber penafsiran yang digunakan pengarang dalam menafsirkan alQur'an; (1) sumber bi al-ma'tsür, yakni berdasarkan pada penjelasan al-Qur'an sendiri, berdasarkan hadis Nabi, pendapat sahabat, dan isräiliyyāt; (2) sumber bi al-ra'yi, yakni berdasarkan ijtihad sang mufassir. Sementara dalam menjelaskan al-Qur'an, metode yang diusung Mujāhid adalah metode ijmāiti, yakni menafsirkan ayat al-Qur'an dengan bahasa yang ringkas, padat, dan tidak panjang lebar. Di samping itu, Mujāhid juga menggunakan metode muqāran meskipun hanya relatif sedikit. Untuk corak penafsirannya, tafsir Mujāhid tidak sampai pada corak disiplin ilmu tertentu, hanya sebatas kental dengan nuansa penafsiran dari gurunya - Ibn 'Abbās, meskipun dalam beberapa penafsiran terdapat corak fiqhi dan kalämi dengan kapasitas yang sangat sedikit.

Kata Kunci: Tabi'in, Mujāhid bin Jabar, Tafsir al-Qur'an.

\section{A. Pendahuluan}

Generasi sahabat Nabi merupakan generasi yang telah sukses menjalankan misinya. Bukti kesuksesan tersebut terealisasi ketika mereka berhasil mendidik beberapa murid dari generasi tabi'in yang kepopulerannya tidak jauh berbeda dengan gurugurunya. Generasi tabi'in yang populer dan fenomenal merupakan hasil edukasi dari sahabat familiar 'Abdullāh Ibn 'Abbās di Makkah, antara lain seperti Sa'ỉd bin Jubair, Mujāhid bin Jabar, 'Ikrimah, Ṭāwūs bin Kisan dan 'Ațā' bin Abì Rabāh. Sedangkan generasi tabi'in murid Ubay bin Ka'b di Madinah, antara lain seperti Abū al-'Āliyah, Zaid bin Aslam dan Muhammad bin Ka’b. Sementara generasi tabi' in murid 'Abdullāh Ibn Mas'ūd di Kufah antara lain seperti 'Alqamah bin Qais, Masrūq, al-Aswad bin Yazid, Murrah al-Hamdānī, 'Āmir al-Syu'bì, al-Ḥasan al-Bașrī dan Qatādah bin Di’āmah al-Sadusi. ${ }^{1}$

1 Madrasah tafsir atau kota-kota tempat kajian tafsir pada masa itu terpusat di tiga tempat yaitu Makkah, Madinah dan Kufah (Irak). 'Abd Allah bin 
Nama-nama tersebut yang kemudian mengemban amanat menggantikan gurunya untuk menyampaikan risalah al-Qur'an dan menjelaskannya sesuai dengan kebutuhan dan tuntutan zaman. Sampai pada periode ini, tafsir al-Qur'an semakin berkembang dan beragam, serta dokumen tafsir al-Qur'an bertambah satu lagi - dimulai dari tafsir Nabi, tafsir sahabat dan tafsir tabi'in. Penafsiran generasi tabi'in ini juga identik dengan penafsiran guru-gurunya, karena sebagian besar masih bercampur dengan riwayat-riwayat hadis. Namun terdapat poin utama yang membedakan tafsir tabi'in dengan tafsir periode sebelumnya, bahwa pada generasi tabi'in penafsirannya sangat kental dengan nuansa penafsiran gurunya masing-masing, sehingga tafsir pada masa ini mulai muncul embrio perbedaan dalam penafsiran dan mulai ada upaya untuk menulis tafsir menjadi suatu kitab tafsir yang mandiri.

Sebagaimana para sahabat, mufassir pada generasi tabi'in tidak semuanya memiliki integritas dan kemampuan yang sama dalam menafsirkan al-Qur'an, sehingga dari buah penafsirannya menghasilkan pemahaman yang berbeda-beda. Kendati demikian, produk hasil penafsiran para tabi'in ini banyak dijadikan sumber rujukan oleh para mufassir berikutnya, seperti tafsir Ibn Jarir alTabari, Ibn Katsīr, al-Suyūtị, dan beberapa mufassir lain hingga berlanjut pada mufassir masa modern bahkan juga abad kontemporer.

Mengacu pada realitas zaman sekarang, generasi muda Islam tidak banyak yang mengenal tafsir karya generasi ketiga dalam dunia Islam, padahal karya tafsir pada masa ini merupakan bagian dari khazanah keilmuan Islam yang sangat fundamental dan berpengaruh pada generasi-generasi berikutnya. Mereka lebih asyik dengan tafsir-tafsir instan yang sudah mapan dan lebih mudah dijangkau, sampai akhirnya mereka melupakan karya-

\footnotetext{
'Abbas sebagai guru tafsir di Makkah, Ubay bin Ka'b sebagai guru tafsir di Madinah dan 'Abd Allah bin Mas'ud sebagai guru tafsir di Kufah. Dari mereka muncul ahli tafsir terkemuka dari kalangan tabi'in. Ciri-ciri khusus penafsiran mereka dari kalangan tabi'in pada waktu itu adalah masuknya kisah-kisah israiliyyat dalam tafsir, dan penafsiran mereka masih terfokus pada riwayat dan sudah mulai tampak benih-benih perselisihan madzhab. Lihat Muhammad Husain al-Dzahabi, al-Tafsir wa al-Mufassirun, Juz I, (Kuwait: Dar al-Nawadir, 2010), hlm. 101-118.
} 
karya tafsir yang tersembunyi ditelan sejarah dan enggan untuk mengungkapnya. Sebagai contoh karya tafsir pada generasi tabi'in, sebut saja tafsir Mujāhid bin Jabar, tafsir Muqātil bin Sulaimān, tafsir al-Ḍahāk, tafsir 'Ikrimah, dan masih banyak lagi tafsir tabi'in yang lainnya.

Mayoritas seseorang yang bergelut di dunia tafsir, khususnya generasi Islam masa kini hampir tidak mengenal tafsir Mujāhid bin Jabar, baik secara umum maupun secara spesifik mulai dari sosok mufassirnya, bentuk konkret kitabnya, corak tafsirnya, dan metode yang digunakan, bagaimana karya sesungguhnya. Tulisan ini bermaksud mengkaji kitab tafsir Mujāhid bin Jabar. Kitab tafsir Mujāhid ini merupakan hasil disertasi dari editor Muhammad 'Abd al-Salām Abū al-Nail untuk meraih gelar Doktor dari Universitas Kairo yang diajukan pada bulan Januari tahun 1976 M, dan diujikan pada sidang munaqasah pada bulan Juni tahun 1976 M bertepatan dengan bulan Jumadil Akhir tahun $1396 \mathrm{H}^{2}$

Untuk mendapatkan pemahaman yang komprehensif, penulis mengkajinya dengan perspektif konstruktivisme, studi kepustakaan dengan data primer tafsir Mujāhid bin Jabar, serta analisa data dengan jenis intertekstualitas. Adapun uraian pembahasannya fokus pada potret kehidupan sang mufassir, sumber-sumber tafsir, metode dan corak tafsir sekaligus contohcontohnya, serta kelebihan dan kekurangan yang ada dalam kitab tafsir Mujāhid.

\section{B. Mujāhid Bin Jabar: Potret Seorang Mufassir Tabi'in}

Mujāhid bin Jabar dikategorikan sebagai salah seorang mufassir tabi'in, sekurangnya dapat dilihat dari dua aspek. Pertama, dari segi zaman hidupnya, ia merupakan generasi setelah sahabat Nabi yang lazim disebut dengan tabi'in. Kedua, dari segi karya tafsirnya, di mana ketika menjelaskan ayat al-Qur'an, ia masih identik dengan pemikiran gurunya - Ibn 'Abbās dan tidak menutup kemungkinan menggunakan ijtihad pemikirannya.

Nama lengkap dari Mujāhid bin Jabar (ada pula yang menyebutnya Mujāhid bin Jubair) adalah Abū al-Ḥajjāj Mujāhid

\footnotetext{
${ }^{2}$ Mujahid Tafsir al-Imam Mujahid bin Jabar., hlm. 24.
} 
bin Jabar al-Makkī al-Makhzūmī al-Muqri'. Selain terkenal sebagai seorang mufassir, Mujāhid juga dikenal sebagai muhaddis (ahli hadis), hafiz (penghafal al-Qur'an), faqīh (ahli fiqih) dan muqri' (ahli qira'at) serta ahli dalam beberapa disiplin ilmu yang digelutinya. ${ }^{3}$

Tokoh ini dilahirkan di Makkah pada tahun $21 \mathrm{H}$ dalam keluarga Muslim pada masa kekhalifahan Umar bin al-Khattāb. Mengenai tahun wafatnya banyak terjadi perbedaan riwayat, ada yang menyebutkan Mujāhid wafat pada tahun $104 \mathrm{H}$ setelah kekhalifahan Umar bin 'Abd al-'Azizz. Ada pula yang mengatakan bahwa tahun wafatnya adalah tahun 100, 101, 102, dan $103 \mathrm{H}$. Namun yang jelas Mujāhid wafat di kota Makkah pada usia 83 tahun dalam keadaan bersujud. ${ }^{4}$ Hal ini mengandung arti bahwa Mujāhid selama hidupnya berada di dua masa pemerintahan Islam, yakni pada masa Khulafā' al-Rāsyidin - Umar bin al-Khattāb dan Banī Umayyah - Umar bin 'Abd al-'Aziz.

Selain Mujāhid merupakan tokoh utama mufassir generasi tabi'in, ia juga merupakan sosok figur yang paling mengetahui tentang tafsir di antara mereka. ${ }^{5}$ Mujāhid adalah murid Ibn 'Abbās yang paling tsiqah, sehingga penafsirannya banyak dirujuk oleh imam al-Syâfi'i, imam al-Bukhärì dan para ulama lainnya sebagai referensi dalam hal tafsir. ${ }^{6}$ Sehingga secara faktual tafsir Mujāhid ini merupakan kitab tafsir yang sangat monumental pada zamannya, bahkan al-Dzahabì menukil suatu riwayat dari 'Abd alSalām bin Hạrb dari Muṣ’ab, ia menyatakan bahwa Mujāhid adalah tabi'in yang paling 'ālim dalam bidang tafsir. ${ }^{7}$

Mujāhid juga merupakan seorang budak, namun terkait tentang siapa majikannya masih terdapat perbedaan. Perbedaan pendapat tersebut berdasarkan pada sumber riwayat berbeda-beda

3 Ahmad bin 'Ali bin Hajar Syihab al-Din al-'Asqalani, Tahdzib alTahdzib, Juz IV, (Turats: Muassasah al-Risalah, t.th), hlm. 25.

${ }^{4}$ Abu al-Fida' Ibn Katsir, al-Bidayah wa al-Nihayah, Juz IX, (Beirut: Maktabah al-Ma'arif, t.th), hlm. 231. Lihat juga, Ibn Hajar al-'Asqalani, Tahdzib al-Tahdzib, Juz IV, hlm. 25-26.

5 Manna' al-Qattan, Mabahits fi Ulum al-Qur'an, (Kairo: Maktabah Wahbah, t.th), hlm. 372.

${ }^{6}$ Ibn Katsir, al-Bidayah wa al-Nihayah., Juz IX, hlm. 224.

${ }^{7}$ Muhammad Husain al-Dzahabi, al-Tafsir wa al-Mufassirun., Juz I, hlm. 104-105. 
yang berasal dari Mujāhid sendiri. Ada yang mengatakan bahwa ia adalah budak dari al-Sāib bin Abī al-Sāib, pendapat ini dikemukakan oleh 'Abd al-Ghani bin 'Abd al-Wāhid al-Maqdisī, dan dipilih oleh al-Dzahabi. ${ }^{8}$

Pendapat lain mengatakan bahwa Mujāhid juga budak dari Qais bin al-Sāib yang disampaikan oleh 'Abd al-Raḥman bin Mahdi, Muș'ab, 'Āli bin al-Madinī, Muhammad bin 'Abd alRahịm, Muhammad bin Sa'd, Abū 'Amr al-Dānì dan Abū Ja'far bin al-Bādzisy. ${ }^{9}$ Namun ada pula yang mengatakan bahwa Mujāhid merupakan budak dari 'Abd Allāh bin al-Sāib, pendapat ini dijelaskan oleh Ahmad bin Hanbal, al-Bukhārì dan Muslim. Dari semua perbedaan pendapat tersebut, pada hakikatnya samasama berdasarkan riwayat dari Mujāhid sendiri. Hal ini mengindikasikan adanya kemungkinan bahwa Mujāhid adalah budak dari beberapa orang. ${ }^{10}$

Pengarang tafsir satu ini masih tergolong dari kalangan tabi'in yang kajian tafsirnya berpusat di Makkah. Menurut riwayat dari beberapa murid Ibn 'Abbās lainnya, Mujāhid adalah tabi'in yang paling sedikit mengambil tafsir dari Ibn 'Abbās,

${ }^{8}$ Pendapat ini berdasarkan riwayat dari Mujahid sendiri dalam Tabaqat karya Ibn Sa'd dari al-Fadl bin Dakin, dari Isma'il bin 'Abd al-Mulk, dari Yunus bin Khabab dari Mujahid, ia berkata bahwa majikannya bernama al-Saib yang buta mengatakan kepadanya: "Wahai Mujahid apakah matahari sudah tergelincir?". Apabila Mujahid menjawab dengan kata "Ya", maka majikannya tadi yakni al-Saib segera berdiri dan menunaikan shalat dzuhur. Lihat Abu alHajjaj Mujahid bin Jabar, Tafsir al-Imam Mujahid bin Jabar, ed. Muhammad 'Abd al-Salam Abu al-Nail (Beirut: Dar al-Fikr al-Islami al-Haditsah, 1989), hlm. 78 .

9 Pendapat ini juga berdasarkan riwayat dari Mujahid ketika menjelaskan surah al-Baqarah ayat 184 tentang kewajiban membayar fidyah dengan memberi makan orang miskin bagi orang yang tidak kuat puasa. Mujahid meriwayatkan bahwa ayat tersebut turun kepada majikannya yang bernama Qais bin Sa'ib yang tidak berpuasa dan diperintahkan untuk memberi makan orang miskin pada setiap hari sesuai dengan puasa yang ditinggalkannya. Lihat Mujahid, Tafsir al-Imam Mujahid bin Jabar., hlm. 77-78.

${ }_{10}$ Pendapat ini juga berdasarkan riwayat dari Mujahid sendiri yang diriwayatkan dari al-A'masy dari Mujahid bahwa ia berkata "Riwayat ini berasal dari majikanku yakni 'Abd Allah bin al-Saib. Lihat Mujahid, Tafsir alImam Mujahid bin Jabar., hlm. 78. 
yakni sebanyak tiga puluh kali. ${ }^{11}$ Diriwayatkan oleh Mujāhid sendiri bahwa ia berkata: "Saya menyodorkan (belajar) mushaf kepada Ibn 'Abbās sebanyak tiga puluh kali. Saya berhenti pada setiap ayat untuk menanyakan pengertiannya, berkenaan dengan apa serta bagaimana pula situasi dan kondisi saat ia diturunkan?". ${ }^{12}$

Mujāhid memang tidak menulis kitab tafsir yang utuh sebagaimana juga para tabi'in lainnya, namun penafsiran dari generasi tabi'in ini - termasuk penafsiran Mujāhid - banyak dinukil ulama setelahnya dalam bentuk periwayatan. Para ahli historis tafsir menengarai pada zaman ini, bahwa tafsir merupakan bagian integral dari kitab-kitab hadis. Dengan kata lain, pada abad kedua ini aktivitas penafsiran lebih banyak berbentuk laporan tentang penafsiran-penafsiran generasi sebelumnya dibanding sebagai hasil kreatifitas mandiri. Mujāhid juga termasuk tipe orang yang tidak mudah puas dengan informasi yang hanya ia dengar tanpa melihat langsung. Sampai akhirnya ia berusaha membuktikan secara empiris informasi-informasi tersebut dengan melakukan perlawatan ke beberapa daerah, seperti Yaman, Mesir, Kufah, daerah-daerah Timur, Madinah, Raudas, Kostantinopel, dan ditempat kelahirannya sendiri. ${ }^{13}$

Dari perjalanannya itu, Mujāhid banyak bertemu dengan tokoh-tokoh intelektual Muslim, dan dari mereka ia banyak meriwayatkan hadis sekaligus telah menjadi gurunya. Di antara

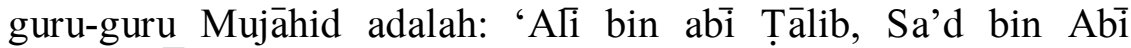
Wāqaș, 'Āisyah binti Abū Bakar, 'Abd al-Raḥman bin Șakhr yang

11 'Abd Allah bin Muhammad bin 'Utsman al-Dzahabi, Mizan al-I'tidal fi Naqd al-Rijal, ed. 'Ali Muhammad al-Bajawi, Juz III, (Beirut: Dar alMa'rifah, t.th), hlm. 439. Lihat juga Muhammad Husain al-Dzahabi, al-Tafsir wa al-Mufassirun., Juz I, hlm. 105.

${ }^{12}$ Manna' al-Qattan, Mabahits fi Ulum al-Qur'an., hlm. 372.

13 Dijelaskan bahwa Mujahid juga melakukan perlawatan ke Konstantinopel, Syam, dan Mesir. Mujahid melakukan perlawatan dan menetap di Kufah dalam waktu yang relatif lama kemudian ia kembali ke Makkah. Mayoritas riwayat menyatakan bahwa Mujahid wafat di Makkah. Adapun Ibn Qutaibah mengatakan bahwa Mujahid merupakan salah satu penduduk Irak. Mujahid juga pernah mengalami kesusahan ketika ia dimasukkan ke dalam penjara oleh penguasa Irak yang pada waktu itu dikuasai oleh al-Hajjaj. Lihat Muhammad Ibn Jarir al-Tabari, Tarikh al-Umam wa al-Muluk wa Akhbaruhum, Juz II, (Kairo: Dar al-Ma’arif, t.th), hlm. 262. 
populer dengan Abū Hurairah, Abū Sa'd bin Mālik, 'Abd Allāh bin 'Amr bin al-'Aș, 'Abd Allāh Ibn 'Abbās, Jabar bin 'Abdullāh, Rāfi' bin Khudaij, 'Abdullāh bin Umar bin Khattāb, Ummu Salamah, Ummu Hāni' dan lain sebagainya. ${ }^{14}$

Sedangkan murid-murid Mujāhid antara lain: 'Ikrimah, Fāọil bin Umar, Qatādah bin Di' āmah, 'Ầtā' bin Abi Rābah, Umar bin Dinār, Muhammad bin Muslim bin Tadarras, Umar bin 'Abdullāh bin Ubaid, Ayyūb bin Kisān, Fatar bin Khalifah, dan 'Abdullāh bin 'Awn. Selain nama-nama tersebut masih banyak nama-nama murid Mujāhid yang tersebar di seluruh penjuru daerah Arab, seperti 'Abd Allāh bin Abì Najịh, 'Abd al-Mālik bin 'Abd al-'Azīiz Sulaimān bin Mihrān, Muslim bin Kisān dan masih banyak lagi yang lainnya. ${ }^{15}$

\section{Kepribadian dan Penilaian Ulama terhadap Mujāhid}

Banyak para ulama menilai Mujāhid adalah sosok yang tsiqah, faqīh, 'ālim, wara', 'ābid dan taqwā. Selain itu, ia juga diakui sebagai imam dalam hal tafsir dan ilmu-ilmu lainnya. Mengenai karyanya, tercatat bahwa tafsir Mujāhid ini adalah satu-satunya karya yang ia tulis. Sedangkan tentang kepribadian Mujāhid, Ibn Sa'd dan Yạ̣yā bin Sa'ìd berkata: "Mujāhid adalah orang yang tsiqah, faqih, 'ālim, dan juga banyak meriwayatkan hadis." Ibn Hibbān berkata: "Mujāhid adalah orang yang faqīh, wara', rajin beribadah dan cermat." Sedangkan al-'Ijli, Ibn Mu'ayyan, dan Abū Zar'ah berkata: "Mujāhid adalah seorang tabi'in Makkah yang tsiqah."

Qatādah bin Di’āmah juga berkata: "Orang yang paling pandai tentang tafsir di antara yang masih ada adalah Mujāhid."

Sementara 'Abd al-Salām bin Harb meriwayatkan dari Muṣ'ab, ia berkata: "Orang yang paling mengetahui tentang tafsir adalah Mujāhid, sedangkan tentang haji adalah 'Ațā'." Sufyān al-Tsauri juga menyatakan: "Ambillah tafsir dari empat orang, yaitu Mujāhid, Sā'id bin Jubair, 'Ikrimah dan al-Ḍaḥāk.” Al-Tsaurī

${ }^{14}$ Ahmad bin 'Ali bin Hajar Syihab al-Din al-'Asqalani, Tahdzib al-

Tahdzib, Juz X, (Beirut: Dar Sadir, t.th), hlm. 42.

${ }^{15}$ Ibn Hajar al-'Asqalani, Tahdzib al-Tahdzib, Juz X, hlm. 42-43.

${ }^{16}$ Mujahid, Tafsir al-Imam Mujahid bin Jabar., hlm. 95. 
menambahkan: "Jika datang kepadamu tafsir dari Mujāhid, maka cukuplah itu bagimu."

Pujian serupa diberikan oleh Muhammad bin 'Utsmān alDzahabi di bagian akhir pembahasan tentang riwayat hidup Mujāhid, di mana ia mengatakan: "Para umat sepakat bahwa Mujāhid adalah tokoh terkemuka yang kata-katanya dijadikan sebagai panutan dan hujjah, dan kepadanya pula 'Abd Allāh bin Katsir belajar." Namun demikian, ada beberapa ulama yang kontra dengan tafsir Mujāhid, sebagaimana al-Dzahabì menjelaskan dengan mengutip riwayat Abū Bakr bin 'Iyāsy, ia berkata: “Aku berkata kepada al-A'masy, apa sebab tafsir Mujāhid kontradiktif? Atau apa alasannya mereka takut untuk mengambil dari tafsir Mujāhid?". Terkait dengan hal ini Ibn Sa'd meriwayatkan, ia berkata: "Mereka berpendapat bahwa Mujāhid bertanya kepada para ahli Kitab."

Dengan demikian, dapat dipahami bahwa hampir semua ulama menilai Mujāhid sebagai orang yang tsiqah. Namun pujianpujian yang dikomentarkan tersebut bukan berarti seseorang harus mengambil semua apa yang disandarkan kepada Mujāhid. Karena sebagaimana perawi lain yang banyak dinukil orang, terkadang di antara penukilnya juga terdapat penukil yang lemah yang tidak tsiqah. Oleh karenanya, penelitian seksama sampai mendapat kepastian akan kesahihan sanad periwayatannya tetap diperlukan. Sikap demikian tidak berbeda dengan ketika menghadapi apa yang diriwayatkan dari Ibn 'Abbās. ${ }^{19}$

\section{Sekilas tentang Tafsir Mujāhid}

Sebagaimana dijelaskan dimuka, bahwa kitab tafsir Mujāhid yang penulis teliti ini merupakan hasil disertasi dari editor Muḥammad 'Abd al-Salām Abū al-Nail untuk meraih gelar Doktor dari Universitas Kairo pada tahun 1976 M/1396 H. Dalam

17 Manna' al-Qattan, Mabahits fi Ulum al-Qur'an., hlm. 372. Lihat juga, Muhammad Husain al-Dzahabi, al-Tafsir wa al-Mufassirun., Juz I, hlm. 105.

${ }^{18}$ Muhammad bin 'Utsman al-Dzahabi, Mizan al-I'tidal., Juz III, hlm. 439. Lihat juga, Muhammad Husain al-Dzahabi, al-Tafsir wa al-Mufassirun., Juz I, hlm. 105.

${ }^{19}$ Manna' al-Qattan, Mabahits fi Ulum al-Qur'an., hlm. 373. 
kajiannya terhadap manuskrip-manuskrip tafsir Mujāhid, Abū alNail berpegang pada riwayat-riwayat Mujāhid yang tersebar dalam kitab-kitab tafsir seperti tafsir al-T abari, tafsir Ibn Katsir, tafsir al-Tsauri, dan tafsir al-Durr al-Mantsūr karya al-suyưți. ${ }^{20}$

Dalam kitab Tärikh al-Turäts al-'Arabỉ dijelaskan, bahwa tafsir Mujāhid ini berasal dari riwayat 'Abdullāh bin Abī Najị̣ di Kairo dan terdapat 8 Kurrāsāt. Sementara al-Tabari menukil riwayat tersebut sebanyak 700 kali dalam beberapa tempat yang berbeda. Adapun jalur yang lain selain 'Abdullāh bin Abi Najị yaitu melalui Ibn Juraij, al-Tsauri, Ma'mar bin Rāsyid 'Abd alRazāq bin Hamām dan Warqā' bin Umar, hingga sampai kepada Mujāhid. ${ }^{21}$

Kitab tafsir Mujāhid ini hanya terdiri dari satu jilid yang memuat penafsiran al-Qur'an dengan redaksi hadis. Bentuk penafsirannya sesuai dengan urutan mushaf, namun tidak secara keseluruhan dan hanya bersifat parsial pada beberapa ayat. Meski demikian, kitab tafsir Mujāhid di samping kredibilitas mufassirnya tidak diragukan, produk tafsirnya juga dinilai cukup representatif untuk membedah dan mengetahui apa dan bagaimana yang diusung oleh pengarang, baik dari segi metode yang digunakan maupun sumber dan corak tafsirnya. Kajian pada kitab tafsir ini dilakukan dengan perspektif konstruktivisme, murni studi kepustakaan yang menitik-beratkan tafsir Mujāhid bin Jabar sebagai data primer, serta analisa data dengan jenis intertekstualitas. Sehingga dengan demikian, akan mudah didapati sekaligus diketahui bagaimana karya sesungguhnya dari sosok mufassir tabi'in, Mujāhid bin Jabar.

\section{E. Metode Tafsir Mujāhid}

Menurut al-Farmāwī, metode yang digunakan mufassir untuk menjelaskan ayat al-Qur'an dapat diklasifikasikan menjadi empat. Pertama, metode tahlili, yaitu mufassir berusaha menjelaskan seluruh aspek yang terkandung dalam al-Qur'an. Kedua, metode ijmäli, yaitu ayat al-Qur'an dijelaskan dengan pengertian garis besarnya saja. Ketiga, metode muqāran, yaitu

${ }^{20}$ Mujahid Tafsir al-Imam Mujahid bin Jabar., hlm. 24.

${ }^{21}$ Fuad Sazkin, Tarikh al-Turats al-'Arabi fi Ulum al-Qur'an, Juz I, (Riyad: Amir Mantaqah, 1991), hlm. 71. 
menjelaskan ayat-ayat al-Qur'an berdasarkan apa yang telah ditulis oleh mufassir sebelumnya dengan cara membandingkannya. Keempat, metode maw mengumpulkan ayat-ayat dibawah suatu topik tertentu kemudian ditafsirkan. $^{22}$

Dalam menafsirkan al-Qur'an, Mujāhid beruasaha menjelaskan ayat secara ringkas, padat, dan tidak panjang lebar. Cara ini juga merupakan ciri khas penafsiran sahabat Ibn 'Abbās. Oleh karena itu, metode penafsiran Mujāhid identik dengan metode penafsiran gurunya, Ibn 'Abbās. Dalam penafsirannya, Mujāhid tidak menafsirkan ayat al-Qur'an secara menyeluruh mulai awal hingga akhir, dan hanya menafsirkan sebagian dari ayat-ayat al-Qur'an dengan bahasa yang ringkas dan padat. Dengan demikian, dapat diambil kesimpulan bahwa metode yang diusung Mujāhid adalah metode ijmā $\bar{i}$.

Bukti bahwa Mujāhid menafsirkan al-Qur'an secara global, tidak panjang lebar, dan juga tidak mencantumkan perangkatperangkat tafsir, seperti asbāb al-nuzūl, munāsabah, nāsikhmansükh dan lain sebagainya, bisa dijumpai ketika ia menafsirkan QS. al-'Ādiyāt [100]: 1-3, sebagai berikut:

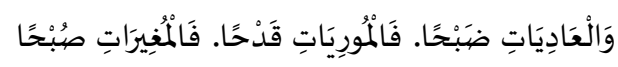

"Demi kuda perang yang berlari kencang dengan terengah-engah, dan kuda yang mencetuskan api dengan pukulan (kuku kakinya), dan kuda yang menyerang dengan tiba-tiba di waktu pagi."

$$
\begin{aligned}
& \text { أَخبرنا عبد الرحمن، قال: ثنا إبراهيم، قال: ثنا آدم، قال: ثنا ورقاءُ عن ابن أَبي نجيح، }
\end{aligned}
$$

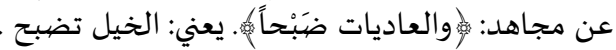

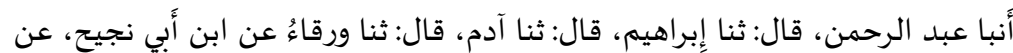

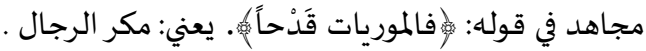

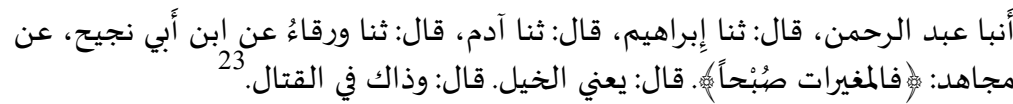

Pada ayat ini, Mujāhid menafsirkan ayat pertama - wa al'ádiyāti ḍaḅ̣a - dengan arti kuda-kuda yang terdengar suaranya ketika lari, ayat kedua - fa al-müriyāti qadhă- ditafsirkan dengan memperdaya kuda-kuda jantan, dan ayat ketiga - fa al-mughïräti

22 'Abd al-Hayy al-Farmawi, al-Bidayah fi at-Tafsir al-Mawdu'i, (Kairo: Dar al-Tiba'ah wa al-Nasyr al-Islamiyyah, 2005), Cet. VII, hlm. 19-36.

${ }^{23}$ Mujahid Tafsir al-Imam Mujahid bin Jabar., hlm. 743. 
subhā - diartikan sebagai kuda-kuda yang digunakan untuk kendaraan perang. Dari penafsiran ini, telah nampak bahwa Mujāhid menafsirkan ketiga ayat tersebut dengan sangat ringkas, padat, dan jelas tanpa memperhatikan perangkat-perangkat tafsir. Metode semacam ini dilakukan Mujāhid pada seluruh ayat alQur'an yang ia tafsirkan, sehingga dapat dikatakan bahwa metode yang digunakan Mujāhid dalam menafsirkan al-Qur'an adalah metode ijmāti.

Selain metode ijmāil, metode penafsiran Mujāhid pun dapat dikategorikan sebagai metode muqāran yang secara aghlabiyyah saja, karena ketika menafsirkan ayat al-Qur'an, Mujāhid mencantumkan beberapa riwayat untuk membandingkan pendapat sahabat satu dengan yang lainnya. Sebagaimana contoh pada QS. al-Takwir [81]: 15-16, yaitu;

$$
\begin{aligned}
& \text { فَلَا أُقْسِمُ بِالْخُنَّسِ. الْجَوَارِ الْكُنَّسِ }
\end{aligned}
$$

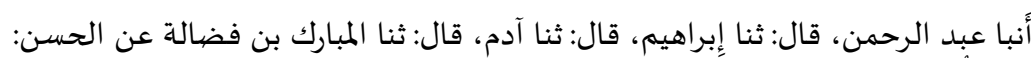

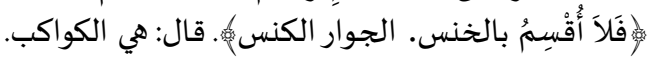

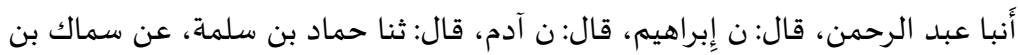

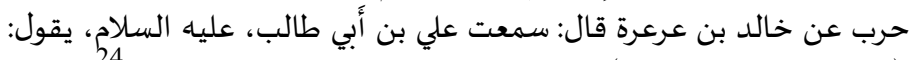

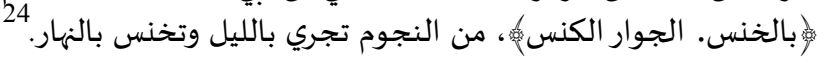

Pada ayat tersebut, Mujāhid menafsirkan ayat falā uqsimu bi al-khunnas - al-jawāri al-kunnas dengan mengutip pendapat sahabat al-Ḥasan yang menafsirkannya dengan arti al-kawākib (bintang-bintang). Di samping itu, Mujāhid juga menafsirkan ayat tersebut dengan mengutip pendapat sahabat sekaligus gurunya, 'A $\bar{i}$ bin abī Ṭālib yang mengartikannya sebagai bintang-bintang yang bersinar di malam hari dan bintang-bintang yang bersinar di siang hari (matahari). Dari penafsiran ini, dapat dipahami bahwa Mujāhid juga menggunakan metode muqāran secara aghlabiyyah dalam penafsirannya. Hal tersebut ia lakukan agar mendapat pemahaman yang utuh dari suatu ayat dengan berpijak pada argumen para sahabat, meskipun dengan kapasitas yang sangat sedikit.

\section{F. Sumber-sumber Tafsir Mujāhid}

${ }^{24}$ Mujahid Tafsir al-Imam Mujahid bin Jabar., hlm. 708. 
Berdasarkan sumber penafsirannya, kitab tafsir Mujāhid termasuk dalam kategori tafsir bi al-ma'tsür, karena dalam menafsirkan al-Qur'an ia menggunakan beberapa riwayat. Selain itu, dalam hal-hal tertentu Mujāhid juga tidak terlepas dari penafsiran bi al-ra'yi, yakni menafsirkan al-Qur'an dengan menggunakan nalar ijtihadnya. Contoh penafsiran Mujāhid dengan menggunakan bi al-ra'yi bisa dijumpai ketika ia menafsirkan QS. al-Zalzalah [99]: 2-5:

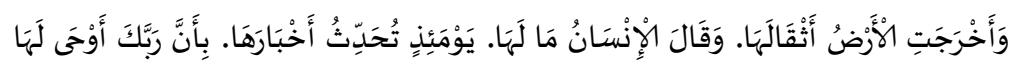

"Dan bumi telah mengeluarkan beban-beban berat (yang dikandung) nya, dan manusia bertanya, "Mengapa bumi menjadi begini)?", Pada hari itu bumi menceritakan berita, karena sesungguhnya Tuhanmu telah memerintahkan (yang sedemikian itu) kepadanya."

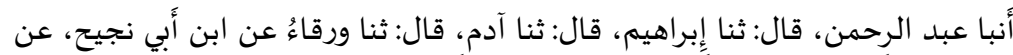

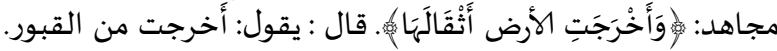

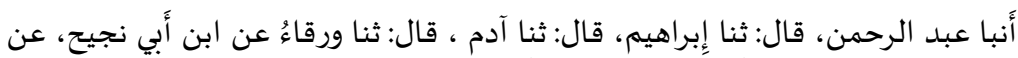

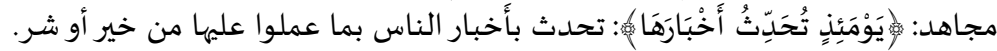

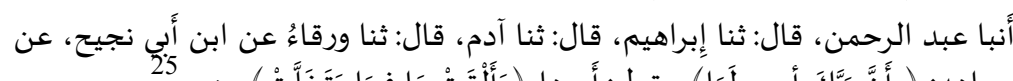

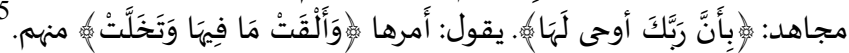

Dalam menafsirkan QS. al-Zalzalah yang terdiri dari delapan ayat, Mujāhid hanya menafsirkan ayat kedua, ketiga, dan kelima. Hal ini membuktikan bahwa tafsir Mujāhid tidak menafsirkan secara keseluruhan ayat dan hanya bersifat parsial pada beberapa ayat. Pada ayat yang kedua wa akhrajati al-ardu atsqālahā, Mujāhid menafsirkan dengan arti bumi mengeluarkan mayat yang ada di dalamnya, sementara ayat keempat yaumaidz tuhadditsu akhbärahā, ia tafsirkan dengan arti menceritakan berita-berita manusia berikut dengan perbuatan yang dilakukannya, baik perbuatan yang terpuji maupun tercela. Sedangkan ayat yang kelima bi anna rabbaka awhālahā, Mujāhid mengartikannya sebagai 'perintah untuk bumi' yang tercantum dalam QS. al-Insyiqāq [84]: 4, "dan dilemparkan apa yang ada di dalamnya dan menjadi kosong”.

Pada penafsiran ayat kelima ini, nampaknya Mujāhid juga menafsirkan al-Qur'an dengan ayat al-Qur'an. Hal ini sedikit

${ }^{25}$ Mujahid Tafsir al-Imam Mujahid bin Jabar., hlm. 742. 
menjadi bukti untuk menyatakan bahwa tafsir Mujāhid juga menggunakan tafsir bi al-ma'tsür dalam sumber penafsirannya. Contoh lain dengan sumber bi al-ma'tsür bisa dilihat pada penafsirannya ketika ia mencantumkan beberapa hadis Nabi dan juga pendapat gurunya - Ibn 'Abbās pada QS. al-Kautsar [108]: 1. Pada ayat ini, Mujāhid memberi penafsiran sebagai berikut;

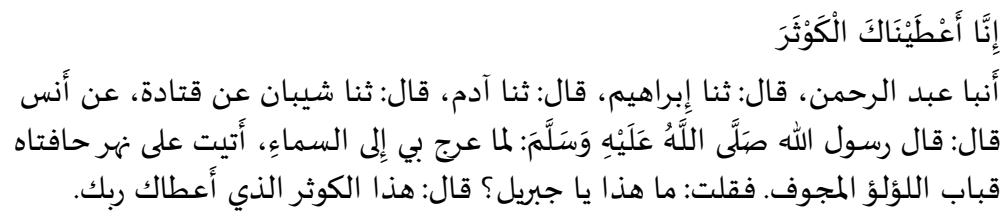

“Telah menceritakan kepada kami 'Abd al-Raḥman, Ibrāhīm, Ādam, Syaibān dari Qatādah dari Anas, ia berkata; Ketika Nabi Saw mengalami peristiwa Mi'raj ke langit, Nabi bersabda: “Aku mendatangi telaga, pada kedua tepinya terdapat Qubah berongga yang terbuat dari mutiara. Maka aku pun bertanya, 'Apa ini wahai Jibrill?" ia menjawab, "Ini adalah al-Kautsar."

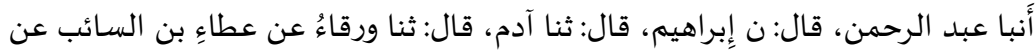

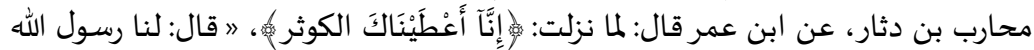

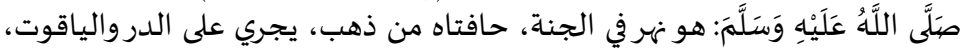

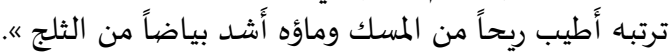

"Telah mengabarkan kepada kami 'Abd al-Rahman, Ibrāhīm, Ādam, Warqā' dari 'Ațā' bin al-Sāib dari Muhārib bin Ditsār, ia berkata, telah menceritakan kepada kami 'Abd Allāh bin Umar ia berkata, ketika turun ayat: innā a'taināka al-kautsar, Rasulullah bersabda: "Itu adalah sungai di dalam surga, kedua tepinya terbuat dari emas, airnya mengalir di atas permata dan yaqut, tanahnya lebih wangi dari minyak misik, rasanya lebih manis dari pada madu, dan airnya lebih putih dari pada salju."

أَنبا عبد الرحمن، قال: ثنا إبراهيم، قال: ثنا آدم، قال: ثنا عيسى ابن ميمون قال: ثنا

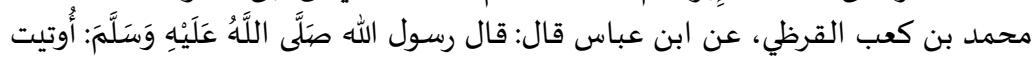

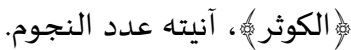

"Telah mengabarkan kepada kami 'Abd al-Rahmman, Ibrāhīm, Ādam, 'Isā ibn Maimūn, Muhammad bin Ka'b, dari Ibn 'Abbās, ia berkata, bahwa Rasullulah Saw bersabda: "al-Kautsar diberikan kepadaku dan sebagai tempat minumnya sejumlah bintang-bintang."

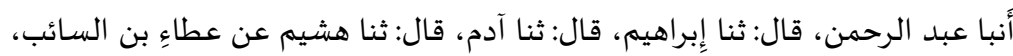

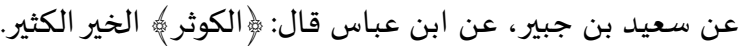


"Telah mengabarkan kepada kami 'Abd al-Raḥman, Ibrāhīm, Ādam, Hasyīm dari 'Ațâ' bin al-Sāib, dari Sa'ìd bin Jubair, dari Ibn 'Abbās, ia berkata, al-Kautsar adalah tempat kebaikan yang melimpah."

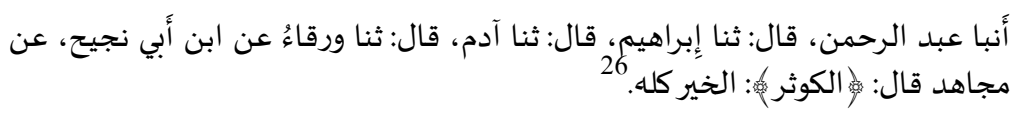

"Telah mengabarkan kepada kami "Abd al-Rahman, Ibrāhīm, Ādam, Warqā' dari Ibn Abì Najịh, dari Mujāhid, ia berkata, al-Kautsar adalah tempat semua kebaikan."

Dari penafsiran tersebut, tampak jelas bahwa Mujāhid dalam menafsirkan QS. al-Kautsar [108]: 1 di atas menggunakan hadis Nabi dan pendapat dari gurunya, Ibn 'Abbās. Hal demikian ia lakukan guna mendapatkan pemahaman yang relevan sesuai yang dikehendakinya. Penafsiran di atas juga membuktikan bahwa selain Mujāhid menggunakan sumber tafsir bi al-ma'tsür, penafsirannya juga dipengaruhi gurunya, Ibn 'Abbās. Dengan demikian cukup kuat landasan untuk menyatakan bahwa tafsir Mujāhid dalam penafsirannya menggunakan sumber tafsir bi alma'tsür, meskipun juga tidak dapat dipungkiri bahwa Mujāhid dalam menafsirkan beberapa ayat al-Qur'an menggunakan sumber tafsir bi al-ra'yi.

Bukti lebih konkret bahwa Mujāhid sebagai murid Ibn 'Abbās dalam hal upaya menafsirkan al-Qur'an yang dimungkinkan mengikuti jejak gurunya dapat dilihat pada penafsiran QS. al-Mà'ūn [107]: 2 yang layak diperhatikan;

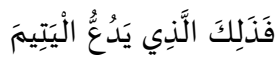

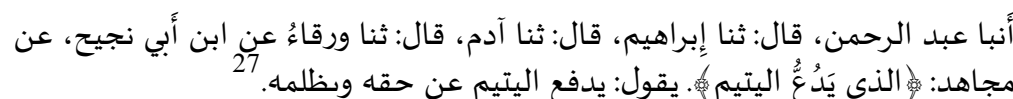

Berikut penafsiran Ibn 'Abbās dalam kitab Tanwïr alMiqbās min Tafsìr Ibn 'Abbās terkait surah dan ayat yang sama;

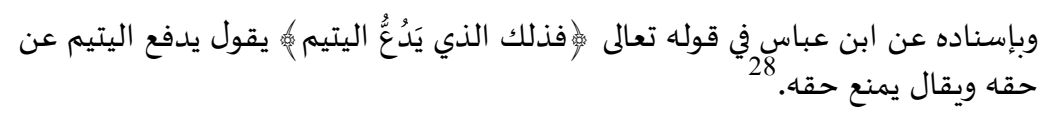

${ }^{26}$ Mujahid Tafsir al-Imam Mujahid bin Jabar., hlm. 756-757.

${ }^{27}$ Mujahid Tafsir al-Imam Mujahid bin Jabar., hlm. 753-754.

28 'Abd Allah Ibn 'Abbas, Tanwir al-Miqbas min Tafsir Ibn 'Abbas (Beirut: Dar al-Kutub al-'Ilmiyah, 1992), Cet. I, hlm. 660. 
Dari penafsiran tersebut, baik tafsir Mujāhid maupun Ibn 'Abbās sama-sama menafsirkan ayat tersebut dengan arti mencegah dari hak-hak anak yatim. Hal ini menunjukkan bahwa penafsiran Mujāhid telah dipengaruhi gurunya, Ibn 'Abbās. Namun demikian, penafsiran Mujāhid dalam kitab tafsirnya tidak seluruhnya mutlak dipengaruhi oleh pemikiran Ibn 'Abbās. Dalam hal-hal tertentu Mujāhid juga mengaplikasikan intelektualnya, khususnya dalam masalah penafsiran yang diperoleh dari gurugurunya yang lain ketika ia mengadakan perlawatan ke berbagai daerah. Selain itu, dari perlawatan ke berbagai daerah juga membuat penafsirannya tidak murni seratus persen beraliran Makkah yang familiar cenderung tradisionalis daripada Irak. Ketidaksamaan Mujāhid dengan gurunya Ibn 'Abbās bukan menjadi persoalan yang alot karena Mujāhid sendiri memiliki dasar dan pijakan yang ia yakini, dan masih tetap dalam koridor seorang mufassir dengan tidak menanggalkan aturan-aturan bagi predikat mufassirnya.

Terlepas dari pengaruh Ibn 'Abbās tersebut, Mujāhid telah memberi kebebasan yang luas atas nalarnya sebagai instrumental dalam memahami sebagian ayat-ayat al-Qur'an. Terkadang ayat yang ia tafsirkan maknanya secara lahiriyah tampak sangat jauh dari kenyataan. Penafsiran Mujāhid ini yang akhirnya diusung oleh golongan Mu'tazilah untuk menafsirkan ayat al-Qur'an dengan berdalih pada dalil yang digunakan Mujāhid. ${ }^{29}$ Penafsiran Mujāhid dengan perumpamaan, misalnya, dapat dilihat ketika ia menafsirkan QS. al-Baqarah [2]: 65 dengan ayat lain, yaitu QS. al-Jumu'ah [62]: 5 .

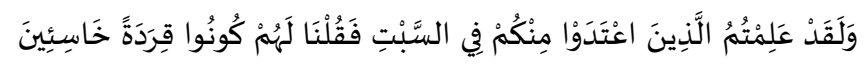

"Dan sungguh telah kamu ketahui orang-orang yang melanggar diantaramu pada hari Sabtu, lalu kami berfirman kepada mereka: "Jadilah kamu kera yang hina."

29 Mujahid dalam menafsirkan al-Qur'an juga melakukan istinbath hukum yang sering dijadikan rujukan oleh al-Syafi'i dalam madzhab fiqhnya. Selain itu Mujahid juga melakukan penafsiran tentang ayat-ayat yang berhubungan dengan ilmu Kalam, kemudian dijadikan rujukan oleh kaum Mu'tazilah, yaitu berkenaan dengan pendapat yang menyatakan bahwa Allah tidak bisa dilihat. Lihat Mujahid Tafsir al-Imam Mujahid bin Jabar., hlm. 139. 


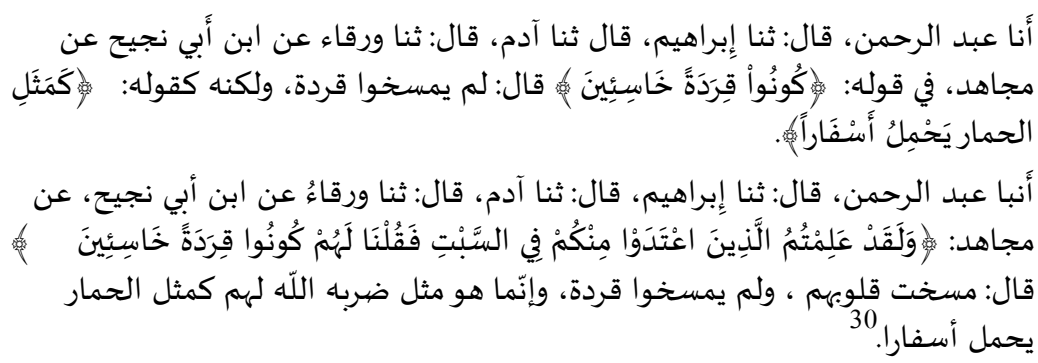

Terkait dengan ayat ini, Mujāhid menafsirkan bahwa ayat kūnu qiradatan khāsi'în berarti diubah hatinya dan bukan diubah wajahnya menjadi kera, sebagaimana Allah juga memberikan permisalan bagi mereka yaitu seperti keledai yang membawa kitab-kitab tebal. Penafsiran dari Mujāhid semacam ini nantinya akan menjadi pedoman yang kuat bagi golongan Mu'tazilah atas pendapat mereka dalam persoalan-persoalan ilmu Kalam. Namun tetap tidak bisa dipungkiri bahwa Mujāhid merupakan seorang imam dalam hal tafsir tanpa ada kontradiksi. Kebebasan diri dalam hal menafsirkan al-Qur'an dengan bi al-ra'yi juga tidak akan mengurangi kedudukan Mujāhid ataupun merendahkan martabatnya. ${ }^{31}$

Terlepas dari hal tersebut, penggunaan isrä'îliyyāt sebagai sumber dalam menafsirkan al-Qur' an juga dilakukan oleh Mujāhid untuk menjelaskan ayat-ayat tertentu yang membutuhkan informasi tambahan terkait dengan kisah-kisah yang ada pada ahli Kitab. Ignaz Goldziher menyebutkan bahwa tokoh-tokoh sumber Yahudi asli ialah seperti Ka'b al-Ahbār dan Wahab bin Munabbah. ${ }^{32}$ Penafsiran menggunakan isräiliyyāt yang dilakukan Mujāhid tampak ketika ia menafsirkan QS. al-A'rāf [7]: 129, sebagai berikut:

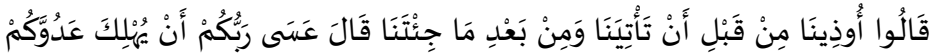

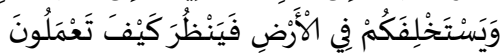

${ }^{30}$ Mujahid Tafsir al-Imam Mujahid bin Jabar., hlm. 141.

${ }^{31}$ Lihat biografi Mujahid dalam Ibn Hajar al-'Asqalani, Tahdzib alTahdzib, Juz X, hlm. 42-43. Lihat juga, Mujahid Tafsir al-Imam Mujahid bin Jabar., hlm. 139.

32 Ignaz Goldziher, Madzahib at-Tafsir al-Islami, terj. M. Alaika Salamullah (Yogyakarta: Elsaq Press, 2006), Cet. III, hlm. 116. 
"Kaum Musa berkata: "Kami Telah ditindas (oleh Fir'aun) sebelum kamu datang kepada kami dan sesudah kamu datang. Musa menjawab: "Mudah-mudahan Allah membinasakan musuhmu dan menjadikan kamu khalifah di bumi-(Nya), Maka Allah akan melihat bagaimana perbuatanmu."

Terkait dengan ayat ini, Mujāhid memberi penafsiran dengan riwayat yang diungkapkan oleh Wahab bin Munabbah yang notabene termasuk dari golongan Yahudi asli yang sering menceritakan kisah-kisah israiliyyät. Riwayat Wahab bin Munabbah tersebut adalah:

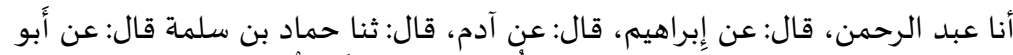

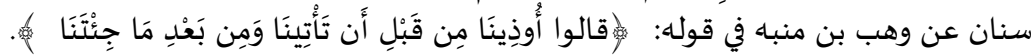

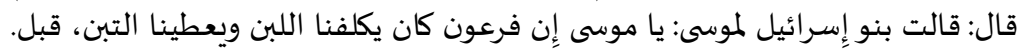

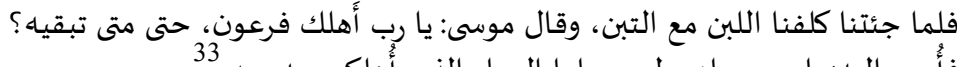

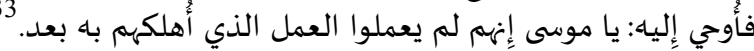

Dari riwayat ini, tampak Wahab bin Munabbah berkata: "Bani Israil telah berkata kepada Musa: "Hai Musa, Fir'aun akan mencukupi kami dengan memberi susu dan jerami sebelum kamu datang kepada kami. Kemudian ketika kami datang, kami menagih susu dengan jerami tersebut, dan Musa berkata: Ya Tuhan, apakah Engkau telah menghancurkan Fir'aun (?), hingga berapa lama Engkau akan menjaganya? Kemudian diturunkan wahyu kepadanya: Hai Musa, mereka belum melakukan perbuatan yang telah Aku hancurkan kepada Fir'aun setelah kamu datang."

Dengan demikian, dapat diambil intisari bahwa Mujāhid memang menggunakan kisah-kisah isräiliyyāt yang bersumber dari Yahudi asli setelah masuk Islam. Mujāhid mengambil riwayat tersebut, di samping hanya dengan kapasitas yang sangat sedikit, ia juga memiliki persepsi yang kuat bahwa riwayat yang ia ambil dari Yahudi asli ini telah dikenal oleh masyarakat Arab dan tidak menimbulkan kerugian dan bahaya bagi agama Islam.

\section{G. Corak Tafsir Mujāhid}

Corak penafsiran pada generasi tabi'in - termasuk juga tafsir Mujāhid - belum mengarah secara spesifik pada madzhab atau aliran, dan juga belum mengarah pada salah satu disiplin

\footnotetext{
${ }^{33}$ Mujahid Tafsir al-Imam Mujahid bin Jabar., hlm. 341.
} 
keilmuan tertentu. Sebab pada masa itu, keilmuan Islam belum begitu banyak berkembang sehingga belum sampai muncul aliranaliran tertentu. Tafsir Mujāhid yang ikut andil dalam mewarnai khazanah keilmuan tafsir di dunia Islam juga tidak terhindarkan dari adanya beberapa tendensi atau kecenderungan yang menjadi salah satu faktor dalam menimbulkan keragaman corak penafsiran.

Corak tafsir Mujāhid ini terbatas pada letak geografis di mana mufassir itu berada, sehingga penafsirannya hanya terpaku pada riwayat-riwayat karena pada periode ini masih bercampur dengan hadis. Secara geografis, paling tidak terdapat tiga aliran yang menonjol pada masa itu, yaitu; (1) aliran Makkah yang dipelopori oleh Ibn 'Abbās; (2) aliran Madinah, tokohnya Ubay bin Ka'b; dan (3) aliran Irak yang diketuai oleh 'Abdullāh bin Mas'ūd. Selain itu ada juga aliran lain yang ikut mewarnai tafsir di era tabi'in, seperti aliran Bashrah yang banyak dipengaruhi oleh aliran Makkah, salah satu tokohnya adalah Ibn Sirin. ${ }^{34}$

Perbedaan yang cukup signifikan dari beberapa aliran ini adalah coraknya. Aliran Makkah dan Madinah masih cenderung bercorak tradisionalis dalam arti lebih banyak menggunakan riwayat. Sedangkan di Irak mulai muncul corak tafsir bi al-ra'yi (rasional). Hal ini terjadi karena kondisi geografis Irak yang cukup jauh dari Madinah sebagai pusat studi hadis, sehingga mereka cenderung menggunakan al-ra'yu (ijtihad) ketika tidak ditemukan riwayat. Di samping itu, secara politis tradisi penafsiran yang cenderung rasional itu mendapat dukungan dari gubernur 'Ammar bin Yasìr yang diangkat oleh khalifah Umar bin Khattāb. ${ }^{35}$

${ }^{34}$ Ibn Taimiyah menjelaskan bahwa manusia yang paling 'alim dan faham terhadap tafsir adalah penduduk Makkah, karena mereka adalah muridnya Ibn 'Abbas seperti Mujahid, 'Ata' bin Abi Rabah, 'Ikrimah, dan lainlain. Begitu juga penduduk Kufah muridnya Ibn Mas'ud dan ulama ahli Madinah seperti Zaid bin Aslam. Oleh karena itu, menurut analisa Ibn Taimiyah bahwa pusat studi tafsir pada waktu itu terdapat di tiga kota yaitu, MakkahMadinah-Kufah (Irak). Lihat Taqiy al-Din Ahmad Ibn Taimiyah al-Harrani, Muqaddimah fi Usul al-Tafsir (Kuwait: Dar al-Qur'an, t.t), hlm. 61. Lihat juga, Mahmud al-Naqrasyi al-Sayyid 'Ali, Manahij al-Mufassirin: Min al-'Asr alAwal ila al-'Asr al-Hadits, Juz I, (Baridah: Maktabah al-Nahdah, 1986), Cet. I, hlm. 32-33.

35 Muhammad bin 'Ali bin Ahmad al-Dausi, Tabaqat al-Mufassirin, Juz II, (Beirut: Dar al-Kutub al-'Ilmiyah, t.th), hlm. 78. 
Dari ketiga pemetaan aliran secara geografis di atas, Mujāhid termasuk pada aliran Makkah karena ia adalah salah satu murid dari Ibn 'Abbās yang notabene sebagai guru tafsir aliran Makkah. Dari sini juga bisa disimpulkan bahwa karya tafsir Mujāhid cenderung bercorak tradisionalis, yakni dalam upaya menafsirkan ayat-ayat al-Qur'an ia masih banyak menggunakan riwayat-riwayat atau lazim disebut dengan tafsir bi al-ma'tsür, di samping juga tidak menutup kemungkinan adanya ijtihad dalam penafsirannya (bi al-ra'yi) - sebagaimana terdapat pada penjelasan sebelumnya.

Dengan demikian, pada masa generasi tabi'in ini belum ada corak khusus dan kecenderungan terhadap keilmuan tertentu. Namun dalam keterangan Abu al-Nail sebagai editor tafsir Mujāhid menjelaskan beberapa tema pembahasan tafsir Mujāhid mengarah kepada ilmu Fiqih dan Kalam. Oleh karena itu, tafsir Mujāhid bisa dikatakan sebagai tafsir yang bercorak fiqhi dan kalämi, meskipun dalam kapasitas yang sangat sedikit.

Tafsir Mujāhid dikatakan bercorak fiqhỉ bisa dilihat hasil ijtihadnya tentang ihsa $\bar{r}$, ihram umrah, memakai celak bagi orang yang ihram diwajibkan membayar fidyah, orang ihram yang membunuh hewan buruan, ahli Makkah yang melakukan haji tamattu', hukum sa'i antara shafa dan marwah yang menurut Mujāhid adalah sunah, dan masih banyak lagi ijtihad-ijtihadnya yang lain. ${ }^{36}$ Salah satu contoh penafsiran Mujāhid yang cukup represantatif dalam corak fiqhï bisa dijumpai ketika ia membahas ihșār dalam QS. al-Baqarah [2]: 196;

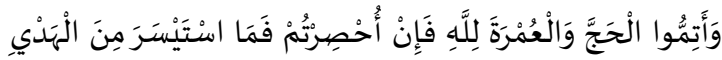

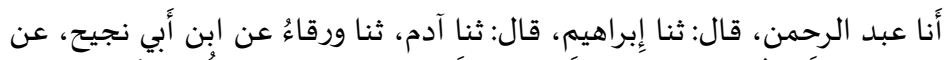

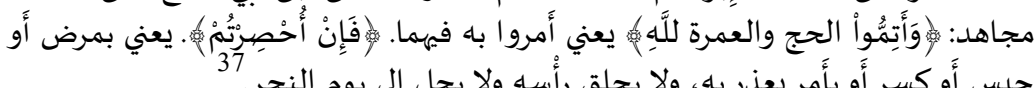

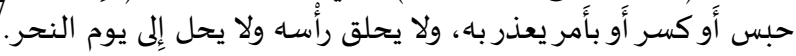

Pada ayat ini, Mujāhid menafsirkan bahwa yang dimaksud $i h s \bar{a} r$ adalah dengan penyakit, hukuman penjara, melanggar aturan atau dengan perintah yang dimaafkan. Iḥsăr juga bermakna tidak mencukur rambut kepalanya sampai hari qurban, yakni pada hari raya 'Idul adha. Penafsiran Mujāhid dengan hasil ijtihad fiqih

\footnotetext{
${ }^{36}$ Lihat Mujahid Tafsir al-Imam Mujahid bin Jabar., hlm. 105-124.

${ }^{37}$ Mujahid Tafsir al-Imam Mujahid bin Jabar., hlm. 105.
} 
semacam inilah yang sebagian dirujuk oleh imam al-Syāfi'’i sebagai kerangka dasar dalam madzhab fiqihnya.

Adapun tafsir Mujāhid yang bernuansa kalāmī dapat dilihat ketika ia membahas dalam tafsirnya mengenai Nabi Isa yang diangkat oleh Allah dalam keadaan hidup, turunnya Nabi Isa ke bumi, dan pembahasan tentang Allah bahwa Dia tidak bisa dilihat. ${ }^{38}$ Sebagai contoh penafsirannya dapat dilihat ketika Mujāhid membahas ayat:

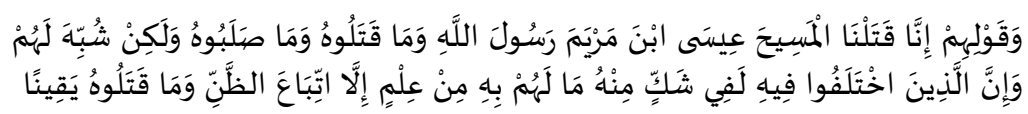

"Dan Karena ucapan mereka: "Sesungguhnya kami Telah membunuh al-Masih, Isa putra Maryam sebagai Rasulullah”, padahal mereka tidak membunuhnya dan tidak (pula) menyalibnya, tetapi (yang mereka bunuh ialah) orang yang diserupakan dengan Isa bagi mereka. Sesungguhnya orang-orang yang berselisih paham tentang (pembunuhan) Isa, benar-benar dalam keragu-raguan tentang yang dibunuh itu. mereka tidak mempunyai keyakinan tentang siapa yang dibunuh itu, kecuali mengikuti persangkaan belaka, mereka tidak (pula) yakin bahwa yang mereka bunuh itu adalah Isa." (QS. al-Nisā' [4]: 157).

Ketika membahas ayat ini, Mujāhid hanya menafsirkan sebagian dari ayat tersebut, yaitu:

$$
\begin{aligned}
& \text { يرى مجاهد رحمه الله أن عيسى عليه سلام رفعه الله إليه حيا . }
\end{aligned}
$$

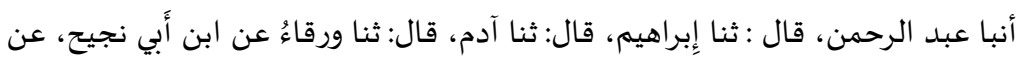

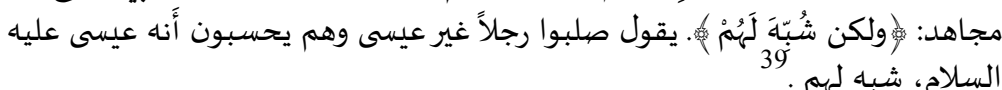

Dalam menafsirkan ayat ini, Mujāhid menyatakan bahwa Allah telah mengangkat Nabi Isa dalam keadaan hidup. Mujāhid kemudian menafsirkan ayat wa lakin Syubbiha lahum dengan arti mereka menyalibkan seorang laki-laki selain Nabi Isa dan mereka menganggapnya sebagai Nabi Isa, padahal hanya orang yang diserupakan dengan Nabi Isa bagi mereka. Contoh penafsiran Mujāhid ini merupakan sebagian yang diusung oleh golongan

\footnotetext{
${ }^{38}$ Lihat Mujahid Tafsir al-Imam Mujahid bin Jabar., hlm. 124-131.

${ }^{39}$ Mujahid Tafsir al-Imam Mujahid bin Jabar., hlm. 124.
} 
Mu'tazilah dalam menafsirkan ayat al-Qur'an dengan berdalih pada dalil atau al-ra'yu yang digunakan Mujāhid.

\section{H. Kelebihan dan Kekurangan Tafsir Mujāhid}

Kualitas tafsir pada generasi tabi'in banyak membuat para ahli berbeda pendapat dalam menjadikannya sebagai dasar atau dalil. Satu pihak menolak hasil penafsiran pada periode tabi'in, karena di samping para tabi' in tidak menyaksikan saat turunnya al-Qur'an, secara kronologis para tabi'in juga tidak mendengar langsung dari Nabi Muhammad Saw atas apa yang mereka tafsirkan. Dengan demikian, boleh jadi para tabi'in keliru dalam memahami apa sesungguhnya yang dimaksud oleh al-Qur'an. Sementara pihak yang menerima hasil penafsiran tabi'in, mereka berdalih bahwa mayoritas tafsir pada generasi tabi'in ini sangat berkaitan denga hasil penafsiran yang dilakukan oleh para sahabat. Pendapat ini merujuk pada perkataan Mujāhid dan Qatādah yang menyatakan bahwa tidak ada satu ayat pun dari alQur'an, kecuali hasil penafsirannya telah didengar oleh sahabat. ${ }^{40}$

Terlepas dari kontradiktif tersebut, dalam menilai penafsiran periode tabi'in, al-Dzahabī menjelaskan bahwa penafsiran mereka ini mempunyai kelebihan dan kekurangan baik pada sumber penafsiran maupun kualitas tafsirnya sendiri. Penilaian untuk tafsir tabi'in yang dilontarkan al-Dzahabi tersebut antara lain:

1. Tafsir pada periode ini memasukkan isräiliyyāt maupun nașrāniyyāt, terutama yang berhubungan dengan berita umat masa lalu dan syariatnya yang disandarkan pada tokoh-tokoh ahli Kitab yang telah masuk Islam.

2. Tafsir pada periode tabi'in menjadi pemelihara dan penyambung periwayatan dari periode sahabat, terutama tafsir bi al-ma'tsür.

3. Embrio perbedaan madzhab atau aliran penafsiran pada periode ini mulai tampak ke permukaan.

${ }^{40}$ Al-Dzahabi, al-Tafsir wa al-Mufassirun., Juz I, hlm. 128-129. 
4. Mulai muncul perbedaan antara tafsir periode tabi'in dan periode sahabat. $^{41}$

Demikian beberapa penilaian yang diungkapkan al-Dzahabi terhadap tafsir periode tabi'in. Tentunya penilaian tersebut juga berlaku pada tafsir karya Mujāhid yang sudah jelas merupakan tafsir dari seorang tabi'in. Selain itu, perlu juga diperhatikan mengenai kredibilitas sosok seorang Mujahid yang hampir tidak ditemukan adanya penilaian negatif terhadapnya. Hemat penulis, ada beberapa kelebihan dan kekurangan yang terdapat dalam kitab tafsir Mujāhid. Adapun kelebihan tafsir Mujāhid menurut analisa penulis, di antaranya sebagai berikut:

1. Penafsiran Mujāhid menggunakan bahasa yang sangat ringkas, padat dan tidak panjang sehingga memudahkan untuk memahaminya.

2. Pembahasan dalam tafsirnya langsung mengarah pada fokus ayat yang ingin ditafsirkan sehingga berkesan tidak berteletele.

3. Penafsiran Mujāhid lebih dominan pada penjelasan redaksi lafadz suatu ayat yang dianggap sulit, sehingga menafikan penafsiran ayat lainnya.

4. Tafsir Mujāhid berdasarkan atas riwayat-riwayat termasuk juga israiliyyāt, sehingga keotentikan hasil tafsirnya lebih bisa dipertanggungjawabkan daripada tafsir yang berdasarkan atas logika semata.

5. Generasi pada masa Mujāhid sangat dekat dengan para sahabat, khususnya pada guru-gurunya, sehingga menjadikan tafsir Mujāhid lebih orisinil dan bersih dari kepentingan. Karena berdasarkan catatan sejarah, Mujāhid bersih dari kepentingan politik maupun aliran tertentu.

6. Tafsir Mujāhid merupakan salah satu tafsir klasik yang sangat langka dan jarang dikaji. Oleh karenanya, kajian tafsir Mujāhid ini merupakan terobosan baru untuk mengkaji lagi dan menelaah kembali tafsir-tafsir abad klasik.

Adapun dari sisi kekurangan tafsir Mujāhid, hemat penulis paling tidak ada enam, di antaranya sebagai berikut:

${ }^{41}$ Al-Dzahabi, al-Tafsir wa al-Mufassirun., Juz I, hlm. 130-131. 
1. Tafsir Mujāhid tidak menafsirkan al-Qur'an secara utuh mulai awal hingga akhir, sehingga pembahasannya tidak runtut alQur'an secara menyeluruh.

2. Bahasa penafsiran Mujāhid yang sangat padat dan singkat, terkadang membuat pembaca kurang menyelami secara mendalam terhadap maksud kandungan ayat.

3. Tafsir Mujāhid bersifat parsial yang terkadang dalam satu surah tidak ditafsirkan semua, sehingga munāsabah dan keutuhan pemahaman dalam satu surah tidak bisa ditemukan.

4. Tafsir Mujāhid tidak menyebutkan apakah isräiliyyāt yang ia riwayatkan termasuk shahih atau dha'if.

5. Tafsir Mujāhid yang aslinya berupa manuskrip-manuskrip catatan yang berceceran bukan dalam satu kitab, sangat rentan terjadi pemalsuan data atau perubahan riwayat-riwayat yang dinisbatkan kepada Mujāhid.

6. Naskah tafsir yang diteliti oleh penulis ialah riwayat tafsir Mujāhid yang hanya memiliki satu jalur, yakni dari 'Abd alRaḥman dari Ibrāhīm dari Ādam dari Warqā' dari Ibn Abì Najị dan sampai pada Mujāhid. Dalam kitab tafsir tersebut tidak disebutkan jalur riwayat yang lain.

\section{Kesimpulan}

Pembahasan dari tulisan ini menghasilkan temuan, sebagai berikut: Pertama, Mujāhid bin Jabar nama lengkapnya adalah Abū al-Hajjāj Mujāhid bin Jabar al-Makki al-Makhzūmī al-Muqri'. Mujāhid selain merupakan seorang budak, ia juga seorang tabi' in murid dari Ibn 'Abbās yang pusat kajian tafsirnya bertempat di Makkah. Tabi'in ini dilahirkan di Makkah pada tahun $21 \mathrm{H}$ dalam keluarga Muslim pada masa kekhalifahan Umar ibn al-Khattāb dan wafat pada tahun $104 \mathrm{H}$ setelah kekhalifahan Umar bin 'Abd al-'Azìiz. Hampir mayoritas ulama menilai bahwa Mujāhid adalah seseorang yang tsiqah.

Kedua, tafsir Mujāhid ini termasuk dalam kategori tafsir $b i$ al-ma'tsür berdasarkan sumber penafsirannya, sementara metode tafsir Mujāhid bersifat ijmā̄i, di samping juga memakai metode muqāran meskipun hanya relatif sedikit. Sedangkan corak tafsir Mujāhid tidak sampai pada corak disiplin ilmu tertentu, hanya 
sebatas kental dengan nuansa penafsiran dari gurunya, walaupun dalam beberapa penafsiran ayat terdapat corak fiqhi dan kalämi

Ketiga, kelebihan dari tafsir Mujāhid ialah penafsirannya menggunakan bahasa yang sangat ringkas, padat dan tidak panjang, pembahasan dalam tafsirnya langsung mengarah pada ayat yang ingin ditafsirkan, penafsirannya berdasarkan pada riwayat dan juga israilizyăt, dan penafsirannya lebih banyak pada penjelasan redaksi lafadz yang dianggap sulit. Sedangkan sisi kekurangan tafsir Mujāhid ialah tafsir Mujāhid tidak menafsirkan al-Qur'an secara utuh mulai awal hingga akhir, tidak menyebutkan apakah israìliyyät yang ia riwayatkan termasuk shahih atau dha'if, penafsirannya bersifat parsial sehingga sulit menemukan makna munāsabah yang utuh, dan bahasa penafsirannya sesekali membuat pembaca kurang memahami terhadap maksud kandungan ayat.

\section{DAFTAR PUSTAKA}

'Abbās, 'Abd Allāh Ibn. Tanwìr al-Miqbās min Tafsìr Ibn 'Abbās. Beirut: Dār al-Kutub al-'Ilmiyah, 1992.

'Ali, Maḥmūd al-Naqrāsyī al-Sayyid. Manāhij al-Mufassirīn: Min al-'Ass al-Awal ila al-'Ass al-Hadits. Baridah: Maktabah al-Nahḍah, 1986.

Al-'Asqalāni, Ahmmad bin 'Ali bin Ḥajar Syihāb al-Dīn. Tahdzīb al-Tahdzìb. Beirut: Dār Șādir, t.th. t.th.

Al-Dausi, Muhammad bin ' $\bar{A} \sqrt{i}$ bin Ahmad. Tabaqàt alMufassirīn. Beirut: Dār al-Kutub al-'Ilmiyah, t.th.

Al-Dzahabī, Muhammad Husain. al-Tafsir wa al-Mufassirūn. Kuwait: Dār al-Nawādir, 2010. 
Al-Dzahabī, 'Abd Allāh bin Muhammad bin 'Utsmān. Mizān alI'tidāl fî̀ Naqd al-Rijāl, ed. 'Ali Muḥammad al-Bajāwìi. Beirut: Dār al-Ma'rifah, t.th.

Al-Farmāwì, 'Abd al-Hayy. al-Bidāyah fî at-Tafsir al-Mawḍ̂','i. Kairo: Dār al-Ṭibā'ah wa al-Nasyr al-Islāmiyyah, 2005.

Goldziher, Ignaz. Madzāhib at-Tafsìr al-Islāmi, terj. M. Alaika Salamullah. Yogyakarta: Elsaq Press, 2006.

Al-Harrāni, Taqiy al-Dīn Ahmad Ibn Taimiyah. Muqaddimah fí Ușūl al-Tafsìr. Kuwait: Dār al-Qur'ān, t.th.

Jabar, Abū al-Hajjāj Mujāhid bin. Tafsìr al-Imām Mujāhid bin Jabar, ed. Muhammad 'Abd al-Salām Abū al-Nail. Beirut: Dār al-Fikr al-Islāmī al-Ḥadisah, 1989.

Katsīr, Abū al-Fidā' Ibn. al-Bidāyah wa al-Nihāyah. Beirut: Maktabah al-Ma'ärif, t.th.

Al-Qațān, Mannā'. Mabāhits fī Ulūm al-Qur'ān. Kairo: Maktabah Wahbah, t.th.

Sazkīn, Fuād. Tărikh al-Turāts al-'Arabī fì Ulüm al-Qur'ān. Riyạ̄: Amīr Manțaqah, 1991.

Al-Ṭabari, Muhammad Ibn Jarìr. Tärikh al-Umam wa al-Mulūk wa Akhbāruhum. Kairo: Dār al-Ma'ārif, t.th. 